DOI: $10.1590 / 1089-6891 v 20 \mathrm{e}-57228$

MEDICINA VETERINÁRIA

\title{
ANTIMICROBIAL ACTIVITY OF ETHANOLIC EXTRACTS FROM Commiphora leptophloeos (MART.) J. B. GILLETT AGAINST Staphylococcus SPP. ISOLATED FROM CASES OF MASTITIS IN RUMINANTS
}

\section{ATIVIDADE ANTIMICROBIANA DO EXTRATO ETANOLICO DA Commiphora leptophloeos (MART.) J. B. GILLETT FRENTE A Staphylococcus SPP. ISOLADOS DE CASOS DE MASTITE EM RUMINANTES}

\author{
Isamara Ferreira da Silva1 ORCID - http://orcid.org/0000-0001-7739-3664 \\ Amanda Leite Guimarães ${ }^{1}$ ORCID - http://orcid.org/0000-0001-8235-6024 \\ Vinícius Santana Amorim ${ }^{1}$ ORCID - http://orcid.org/0000-0001-8657-3202 \\ Telma Maria Guedes da Silva² ORCID - http://orcid.org/0000-0001-5778-0384 \\ Rodolfo de Moraes Peixoto $3^{*}$ ORCID - http://orcid.org/0000-0002-5757-5935 \\ Xirley Pereira Nunes ${ }^{1}$ ORCID - http://orcid.org/0000-0002-9714-8575 \\ Tânia Maria Sarmento Silva² ORCID - http://orcid.org/0000-0003-1887-2598 \\ Mateus Matiuzzi da Costa1 ORCID - http://orcid.org/0000-0002-9884-2112 \\ 1 Universidade do Vale do São Francisco, Petrolina, PE, Brazil. \\ ${ }^{2}$ Universidade Federal Rural de Pernambuco, Recife, PE, Brazil. \\ ${ }^{3}$ Instituto Federal do Sertão Pernambucano, Petrolina, PE, Brazil. \\ *Corresponding author - rodolfo.peixoto@ifsertao-pe.edu.br
}

\begin{abstract}
Considering the therapeutic potential of medicinal plants as alternatives to antibiotic therapy, the research aims to evaluate the antimicrobial activity of Commiphora leptophloeos against isolates of Staphylococcus spp. from the milk of ruminants with subclinical mastitis. For this, the crude ethanolic extract from the bark and leaves of Commiphora leptophloeos was prepared, with these being chemically characterized by HPLC-DAD-MS and by MALDI-TOF. The extracts were then evaluated as to their antimicrobial effects against 60 isolates of Staphylococcus spp. through the broth microdilution technique to determine the minimum bactericidal concentration. In addition, the extracts were evaluated as to their ability to interfere with biofilm formation and with the already established biofilm. Although all tested extracts showed antimicrobial action, lower MBC values were recorded for the bark extract in the concentration $781.2 \mu \mathrm{g} / \mathrm{mL}(25 / 60)$. The extracts of the bark and leaves were able to interfere with the initial stages of biofilm formation, but there was no interference of the extract on the established biofilm. There was a high sensitivity of Staphylococcus spp. isolates from subclinical mastitis cases in ruminants when subjected to the extracts from bark and leaves of Commiphora leptophloeos, as well as regarding the ability of extracts to interfere in biofilm formation, indicating their potential in the use for ruminant mastitis therapy.
\end{abstract}

Keywords: Mastitis, Staphylococcus spp., imburana de cambão, phytotherapy, biofilm.

\section{Resumo}

Considerando o potencial terapêutico de plantas medicinais como alternativas à antibioticoterapia, a pesquisa visa avaliar a atividade antimicrobiana de Commiphora leptophloeos contra isolados de Staphylococcus spp. de leite de ruminante com mastite subclínica. Para isso, foi elaborado o extrato etanólico bruto da casca e folhas de Commiphora leptophloeos, sendo as mesmas caracterizadas 
quimicamente por HPLC-DAD-MS e por MALDI-TOF. Os extratos foram então avaliados quanto aos seus efeitos antimicrobianos contra 60 isolados de Staphylococcus spp pela técnica de microdiluição em caldo para determinação da concentração bactericida mínima. Além disso, os extratos foram avaliados quanto à sua capacidade de interferir na formação do biofilme e com o biofilme já consolidado. Apesar de todos os extratos testados terem apresentado ação antimicrobiana, valores menores de CBM foram registrados para o extrato da casca na concentração $781,2 \mu \mathrm{g} / \mathrm{mL}(25 / 60)$. Os extratos da casca e das folhas foram capazes de interferir nos estágios iniciais da formação do biofilme, mas não ocorreu interferência do extrato no biofilme consolidado. Houve alta sensibilidade do isolados testados quando submetidos a extratos de folhas e casca de Commiphora leptophloeos, bem como a capacidade de extratos interferirem na formação de biofilme, indicando seu potencial uso na terapia de mastite de ruminantes.

Palavras-chave: Mastite, Staphylococcus spp, Imburana de Cambão, Fitoterapicos, biofilme.

Received on; February 14, 2019.

Accepted on June 17, 2019.

\section{Introduction}

Mastitis is one of the infectious diseases that have caused the most damage to the dairy industry throughout the world, with substantial losses in all stages of production ${ }^{(1,2,3)}$. The negative effects of this disease stem from the high cost of its treatment and the administration of antibiotics, also resulting in diminished milk production, discard of the milk contaminated with antimicrobial agents, and the emergence of resistant bacteria ${ }^{(4,5)}$. The clinical manifestation of mastitis is characterized by physical changes in the mammary glands ${ }^{(6)}$. The subclinical form has no symptoms and is determined by a high somatic cell count in the milk. Subclinical mastitis reduces milk quality and can disseminate bacterial infection among different properties and $\operatorname{species}^{(7)}$. Diagnosis and control are complex and require disinfection of the teats, somatic cell counts, bacteriological analysis of the milk, antibiotic therapy and the slaughter of cows with chronic infection ${ }^{(8,9,7)}$. Subclinical mastitis has a multifactor etiology, with bacterial infection frequently reported in the literature. Species of the genus Staphylococcus are the most commonly isolated bacteria in cases of intramammary infection in ruminants ${ }^{(10,11)}$.

The treatment of mastitis is complex and requires the use of broad-spectrum antimicrobial agents with systemic and localized action. However, the emergence possibility of resistant strains is one of the primary repercussions in the use of antibiotics for the treatment of infectious diseases ${ }^{(12,13)}$. Tolerance to antimicrobial agents occurs due to the presence of resistance genes in bacterial chromosomes or plasmids. These genes allow bacteria to express enzymes capable of destroying antimicrobial molecules, modifying the target sites of the drug or creating an alternative metabolic pathway ${ }^{(14,15)}$. The most important genes associated with the resistance to Staphylococcus spp. are related to the production of $\beta$-lactamase, which, in some cases, may be mediated by the blaZ gene, thereby conferring resistance to the $\beta$-lactam class of antimicrobial agents and leading to biofilm formation, which is one of the main responsible factors for persistent or chronic bacterial infection ${ }^{(16,17,18)}$.

Due to current concerns regarding the emergence of bacteria that are resistant to commercial antibiotics commonly employed in the treatment of subclinical mastitis in ruminants, the search for novel compounds with antibacterial action and their potential to reduce or prevent the formation of biofilm is particularly important in the context of animal production. Indeed, the pharmaceutical market has sought new sources of metabolites with antimicrobial activity, such as plants used in 
folk medicine, that meet the same criteria of effectiveness, safety, and quality control as synthetic compounds $^{(8,19,20,21)}$.

Commiphora leptophloeos (Mart.) J. B. Gillett is a thorny tree commonly known as Imburana de Cambão and Imburana of thorns, belonging to the Burseraceae family, which comprises more than 150 species $^{(22,23)}$. Adapted to tropical and subtropical regions, this species is known for its medicinal properties, related to the presence of bioactive compounds in the plant metabolism, traditionally used in local communities in Northeastern Brazil as an infusion, tea or syrup for the treatment of infectious and inflammatory symptoms ${ }^{(24,25,26)}$. Despite its therapeutic value in folk medicine, there are still few scientific reports on the pharmacological activity of Commiphora leptophloeos and its bioactive potential, justifying an emerging interest to study the antimicrobial potential of this species as a possible alternative in the treatment of mastitis in ruminants. Therefore, the present study aimed to evaluate the in vitro antimicrobial activity of ethanolic extracts from the bark and leaves of Commiphora leptophloeos (Mart.) J. B. Gillett against Staphylococcus spp. isolated from cases of subclinical mastitis in ruminants, as well as to perform a phytochemical evaluation of the composition of the crude ethanolic extract of the bark and leaves of C. leptophloeos.

\section{Materials and Methods}

Sixty isolates of Staphylococcus spp. were obtained from cases of subclinical mastitis in cattle (39), buffaloes (14) and goats (07) in dairy properties of the Northeastern region of Brazil, being stored at the Microbiology and Animal Immunology Laboratory of the Department of Veterinary Medicine of the Federal University of São Francisco Valley (UNIVASF), Brazil. Sixteen isolates were classified as coagulase-negative staphylococci (CoNS), whereas 44 were coagulase-positive (CoPS). The isolates were divided based on the presence/absence of the blaZ gene as well as due to a strong/moderate biofilm formation (Table 1).

Table 1. Origin and classification of the isolates of Staphylococcus spp. used in the present study

\begin{tabular}{|c|c|c|c|c|c|c|c|}
\hline \multirow[t]{2}{*}{ Species } & \multirow[t]{2}{*}{ Collection site } & \multirow[t]{2}{*}{ Isolates } & \multirow[t]{2}{*}{ Quantity } & \multicolumn{2}{|c|}{ BlaZ } & \multicolumn{2}{|c|}{ Biofilm } \\
\hline & & & & $\mathrm{PO}$ & $\mathrm{NE}$ & $\mathrm{MO}$ & ST \\
\hline \multirow[t]{2}{*}{ Cattle } & Milk & CPS & 37 & 36 & 1 & 23 & 14 \\
\hline & & $\mathrm{CNS}$ & 2 & 1 & 1 & 1 & 1 \\
\hline Buffalo & Milk & $\mathrm{CNS}$ & 14 & 6 & 8 & 4 & 10 \\
\hline Goat & Milk & CPS & 7 & 2 & 5 & 7 & -* \\
\hline Total & & & 60 & 45 & 15 & 35 & 25 \\
\hline
\end{tabular}

The Kirby-Bauer method was employed based on the CLSI recommendations ${ }^{(27)}$ for the in vitro sensitivity tests compared to commercial agents. Ampicillin $(10 \mu \mathrm{g})$, penicillin $\mathrm{G}(10 \mu \mathrm{g})$ and oxacillin $(10 \mu \mathrm{g})$ (Laborclin $\left.{ }^{\circledR}\right)$ were used to determine the resistance profile of the isolates to the main $\beta$-lactams routinely used for the treatment of subclinical mastitis. The inhibition zone was measured and compared with the CLSI tabulation ${ }^{(27)}$ for the determination of resistance or sensitivity of the sample to the antimicrobial. The results were expressed as resistant or sensitive to antibiotics, 
following the recommendation of the manufacturer of the disc.

The crude ethanolic extracts were obtained from the bark and leaves of C. leptophloeos plants collected in the city of Petrolina (state of Pernambuco, Brazil), at the Campus of Agrarian Sciences of the UNIVASF, within the scope of the C1 Irrigation Perimeter $\left(09^{\circ} 19^{\prime} 47.22^{\prime \prime} \mathrm{S}, 40^{\circ} 33^{\prime} 22.39^{\prime \prime}\right.$ W; elevation: $392 \mathrm{~m}$ ), located in the semiarid region (Caatinga biome) (Figure 1). The bark and leaf material was dried in a drying oven with circulating air at $40{ }^{\circ} \mathrm{C}$ for five days. The bark $(446 \mathrm{~g})$ and leaf $(215 \mathrm{~g})$ samples were then grinded separately and subjected to ethanolic extraction, followed by filtering and concentration in a rotary evaporator at a mean temperature of $50{ }^{\circ} \mathrm{C}$ to obtain the crude ethanol extracts of the bark (105.56 g) and leaves $(45.99 \mathrm{~g})$. Four extractions were performed at $72-$ hour intervals for the maximum extraction of the chemical constituents. The extracts were diluted in $95 \%$ ethanol and used in the in vitro antimicrobial activity assays.

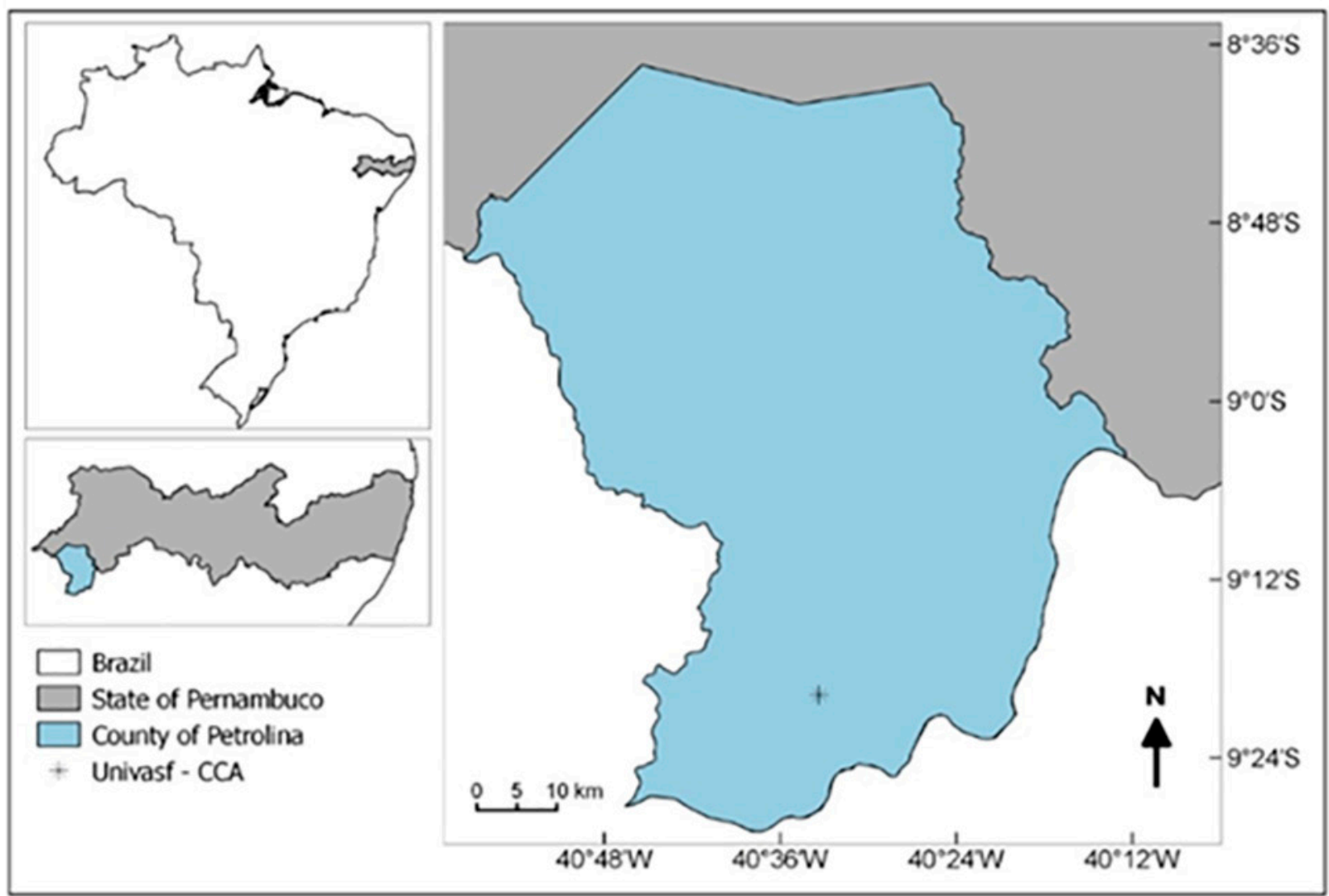

Figure 1. Map of Brazil with highlight to the area of collection, Petrolina, PE

For the data analysis by HPLC-DAD method, the leaf extract of $C$. leptophloeos was extracted in SPE C-18 (solid phase extraction). The cartridge was activated with $10 \mathrm{~mL}$ of methanol and $10 \mathrm{~mL}$ of ultrapure water. Approximately $420 \mathrm{mg}$ of extract was dissolved in $500 \mu \mathrm{L}$ of acidified water $(\mathrm{pH}$ 2 with $\mathrm{HCl}$ ) and $500 \mu \mathrm{L}$ of methanol. Following the placement of the extract into the cartridge, 10 $\mathrm{mL}$ of ultrapure water was added and the fraction with the organic compounds was eluted with 10 $\mathrm{mL}$ of methanol. The solvent was then evaporated, obtaining $84.8 \mathrm{mg}$. This methanolic fraction was analyzed (HPLC-DAD and LC-MS) using a Shimadzu Prominence HPLC (LC-20AT®)(1) with a diode-array detector (SPDM20 $\left.{ }^{\circledR}\right)^{(2)}$. Chromatographic separation was performed in a Luna C-18 column (Phenomenex) measuring $250 \mathrm{~mm} \times 4.6 \mathrm{~mm} \times 5 \mu \mathrm{m}$, the mobile phase of which was a mixture of $\mathrm{H}_{2} \mathrm{O}$ :acetic acid (99:1, Solvent A) and methanol (Solvent B). The leaf extract (SPE) was 
analyzed using LC-MS. LC-ESI-MS/MS was obtained in the negative mode. The bark ethanolic extract $(200 \mathrm{mg})$ was dissolved in acidified water $(\mathrm{pH} 2$ with $\mathrm{HCl})$ and subjected to solid-phase extraction (SPE C-18), being previously activated and eluted with 10, 30, 50, 70 and 100\% of acetone and water. The crude ethanolic extract as well as the $10 \%(23.9 \mathrm{mg}), 30 \%(55.1 \mathrm{mg})$ and $50 \%(16.0 \mathrm{mg})$ fractions were subjected to Matrix-Assisted Laser Desorption/Ionization Time-of-Flight (MALDITOF) mass spectrometry (Autoflex III, Bruker Daltonics, Billerica, MA, USA $\left.{ }^{\circledR}\right)^{(3)}$. The compounds were identified by MS data through fragmentation and precise mass measurements using an internal calibrant (standard peptide mixture).

The microdilution was performed on microplates using the method described in the M07-A9 standard of the manual of the Clinical and Laboratory Standards Institute ${ }^{(28)}$. A total of $0.25 \mathrm{~g}$ of the bark and leaves extract was separately diluted in $10 \mathrm{~mL}$ of ethanol $(95 \%)$, obtaining stock extracts at a concentration of $25,000 \mu \mathrm{g} / \mathrm{mL}$. Following the methodology, the inoculums were prepared from a bacterial suspension with turbidity equivalent to 0.5 in the McFarland standards and taken to an air circulation oven at $37^{\circ} \mathrm{C} / 24 \mathrm{~h}$ under aerobic conditions. For the determination of the $\mathrm{MBC}$, aliquots $(10 \mu \mathrm{l})$ were withdrawn from the liquid material, seeded on Mueller-Hinton agar and incubated again $\left(37^{\circ} \mathrm{C} / 24 \mathrm{~h}\right.$ ). The MBC was defined as lowest concentration of the bark and leaves extract with bactericidal potential against Staphylococcus spp. The tests were conducted in triplicate, and a control of $95 \%$ ethanol was considered.

The capacity of the extract to interfere with the formation of biofilm was determined using the method described by ${ }^{(29)}$. The bacterial isolates were cultivated in $3 \mathrm{~mL}$ of Trypticase soy agar (TSA) broth containing glucose $(1 \%)$ and incubated at $37^{\circ} \mathrm{C}$ for 24 hours. $100 \mu \mathrm{L}$ of the solution was added to microplate wells that had previously received $100 \mu \mathrm{L}$ of the culture medium (negative control). The extract concentration was half of the $\mathrm{MBC}$ value determined in the microdilution assay (0.5 MBC). After 24 hours of incubation at $37^{\circ} \mathrm{C}$, the wells were rinsed three times with $200 \mu \mathrm{L}$ of distilled water, stained with $100 \mu \mathrm{L}$ of gentian violet $(0.25 \%)$ for three minutes and rinsed again with 200 $\mu \mathrm{l}$ of distilled water. Afterward, $200 \mu \mathrm{L}$ of alcohol-acetone was used to dilute the violet crystals. Absorbance was measured in a microplate reader (Elisa Easy® kit) at $620 \mathrm{~nm}$. S. epidermidis ATCC 12228 was used as the negative control, whereas S. aureus ATCC 25923 was used as the positive control.

The capacity of the extracts to affect the established biofilm was determined based on the method described by ${ }^{(29)}$. Biofilm was formed by the incubation of $100 \mu \mathrm{L}$ of bacterial inoculum in microplate wells at $37^{\circ} \mathrm{C}$ for 24 hours. The wells were then washed three times with distilled water for the removal of non-adhered cells and $200 \mu \mathrm{L}$ of the extract $(0.5 \mathrm{MBC})$ was added. The OD was determined immediately after this proceeding, as well as 24 hours after the addition of the extract. Absorbance was measured in a microplate reader (Expert Plus model, Biochrom $\left.{ }^{\circledR}\right)^{(4)}$ at $620 \mathrm{~nm}$. The effect of the extract on the established biofilm was defined by the following equation: mean OD of treated wells/ mean OD of control wells x 100.

The Kolmogorov-Smirnov test revealed non-normal distribution of the data referring to the MBC of the two types of extract. Base 10 logarithmic transformation $\left(\log _{10}\right)$ was performed, but it was also insufficient to remove the heterogeneity of the variances. Therefore, the nonparametric Wilcoxon test was used for pairwise comparisons of mean MBC values of the two extracts. The Mann-Whitney test was used for the comparisons of the MBC between the isolates (coagulase-positive vs. coagulasenegative; blaZ present vs. blaZ absent). The Statistical Package for the Social Sciences (SPSS, version 20.0 for WindowsTM) ${ }^{(5)}$ was used for all data analyses. 


\section{Results}

Out of all the isolates employed in this study, 34 showed resistance to penicillin, 30 to ampicillin and 15 to oxacillin, and several isolates were resistant to more than one antimicrobial (Table 2). The results of the sensitivity test were compared based on the genotypic classification for the presence of the blaZ gene. Among the 46 isolates with the blaZ gene, only ten were sensitive to all $\beta$-lactam antimicrobials tested (Table 2).

Table 2. Resistance profile of Staphylococcus isolates according to the presence/absence of blaZ gene

\begin{tabular}{ccccc}
\hline Phenotypic resistance & CPS blaZ & CPS blaZ - & CNS blaZ + & CNS blaZ - \\
\hline PEN G & 2 & $-*$ & 1 & - \\
AMP & 2 & 1 & - & - \\
OXA & 3 & - & 1 & 2 \\
PEN G, AMP & 20 & 2 & - & 1 \\
PEN G, OXA & 1 & - & 3 & - \\
PEN, AMP, OXA & 4 & - & 1 & - \\
Total & 32 & 3 & 6 & 3 \\
\hline
\end{tabular}

* $(-)$ sensitivity to the antimicrobial

$\mathrm{CPS}=$ coagulase-positive staphylococci, $\mathrm{CNS}=$ coagulase-negative staphylococci

PEN G= penicillin $G, A M P=$ ampicillin, $O X A=$ oxacillin

The analysis of the HPLC-DAD and HPLC-ESI-MS data (Table 3) allowed the identification of the four main components of the C. leptophloeos leaves, which were the C-glycosyl flavones isoorientin, orientin, isovitexin, and vitexin. The ESI-MS spectrum in the negative mode, referring to Peaks 1 and 2 (Figure 2 and Table 3), exhibited the same value in the mass spectrum at $\mathrm{m} / \mathrm{z} 447$, suggesting that these compounds are the isomers isoorientin and orientin. The same was found for Peaks 3 and 4 at $\mathrm{m} / \mathrm{z} 431$, suggesting that these are the isomers vitexin and isovitexin. Other phenol peaks appeared in the spectra, but identification was not possible. Flavonoids have been previously isolated and identified in the aerial parts of C. leptophloeos ${ }^{(30)}$. However, this is the first time that C-glycosyl flavonoids have been reported in the genus Commiphora.

Table 3 - Identification of C-glycosyl flavones in leaves of Commiphora leptophloeos

\begin{tabular}{lllll}
\hline Number & TR (Min) & $\begin{array}{l}{[\mathrm{M}-\mathrm{H}]^{-}} \\
(\mathrm{m} / \bar{z})\end{array}$ & $\begin{array}{l}\text { UV max } \\
(\mathrm{nm})\end{array}$ & Identification \\
\hline 1 & 18.29 & 447 & 267,348 & Isoorientin \\
2 & 19.72 & 447 & 269,348 & Orientin \\
3 & 22.81 & 431 & 269,337 & Vitexin \\
4 & 25.80 & 431 & 256,352 & Isovitexin \\
\hline
\end{tabular}

The MALDI-TOF and MALDI-MS/MS spectra allowed the identification of flavan-3-ol units and galloyl bonds in the oligomers. Condensed tannins (proanthocyanidins) were identified in the fraction obtained with $10 \%$ acetone, with the occurrence of prorobinetinidin units (A Series) (Figure 3) due to the consecutive loss of $288 \mu$. Peaks were observed from two $(\mathrm{m} / \mathrm{z} 601,[\mathrm{M}+\mathrm{Na}]+)$ to seven $(\mathrm{m} / \mathrm{z}$ $2041[\mathrm{M}+\mathrm{Na}]+)$ units of prorobinetinidin. $\mathrm{C}$ series proanthocyanidins were also found in this fraction (Figure 3), with two units of prorobinetinidin and one unit of prodelphinidin (m/z $905[\mathrm{M}+\mathrm{Na}]+)$. For this series, peaks were found at $\mathrm{m} / \mathrm{z} 1193[\mathrm{M}+\mathrm{Na}]+$, corresponding to three units of prorobinetinidin 
and one of prodelphinidin; $\mathrm{m} / \mathrm{z} 1481[\mathrm{M}+\mathrm{Na}]+$, corresponding to four units of prorobinetinidin and one of prodelphinidin; $\mathrm{m} / \mathrm{z} 1769[\mathrm{M}+\mathrm{Na}]+$, corresponding to five units of prorobinetinidin and one of prodelphinidin; and $\mathrm{m} / \mathrm{z} 2057$ [M+Na]+, corresponding to six units of prorobinetinidin and one of prodelphinidin. The fraction obtained with $50 \%$ acetone exhibited only one peak at $\mathrm{m} / \mathrm{z} 871[\mathrm{M}+\mathrm{Na}]+$, corresponding to one unit of profisetinidin and two units of prorobinetinidin. Figure 3 displays the polymeric structures, which were confirmed by the MS/MS spectra. The fraction obtained with 50\% acetone had a profile with hydrolysable tannins, which differed from the other analyzed fractions. The MS/MS spectra demonstrated peaks with losses of $152 \mu$, which corresponds to gallic acid and confirms the presence of gallotannins in the fraction. The present data on condensed tannins are in agreement with findings previously reported for the bark of $C$. leptophloeos ${ }^{(31)}$. However, the presence of gallotannins in the bark of C. leptophloeos is reported for the first time in the present investigation.<smiles>[R6]c1ccc(-c2cc(=O)c3c([R])c([R2])c([R3])c([R4])c3o2)cc1[R6]</smiles>

1 Isoorientina R1=R3=R5=R6=OH, R4=H, R2=Glicose

2 Orientina $\mathrm{R} 1=\mathrm{R} 3=\mathrm{R} 5=\mathrm{R} 6=\mathrm{OH}, \mathrm{R} 4=\mathrm{Glicose}, \mathrm{R} 2=\mathrm{H}$

3 Vitexina $\mathrm{R} 1=\mathrm{R} 3=\mathrm{R} 6=\mathrm{OH}, \mathrm{R} 2=\mathrm{R} 5=\mathrm{H}, \mathrm{R} 4=\mathrm{Glicose}$

4 Isovitexina $\mathrm{R} 1=\mathrm{R} 3=\mathrm{R} 6=\mathrm{OH}, \mathrm{R} 4=\mathrm{R} 5=\mathrm{H}, \mathrm{R} 2=\mathrm{Glicose}$

[Isoorientin; Orientin; Vitexin; Isovitexin; Glucose]

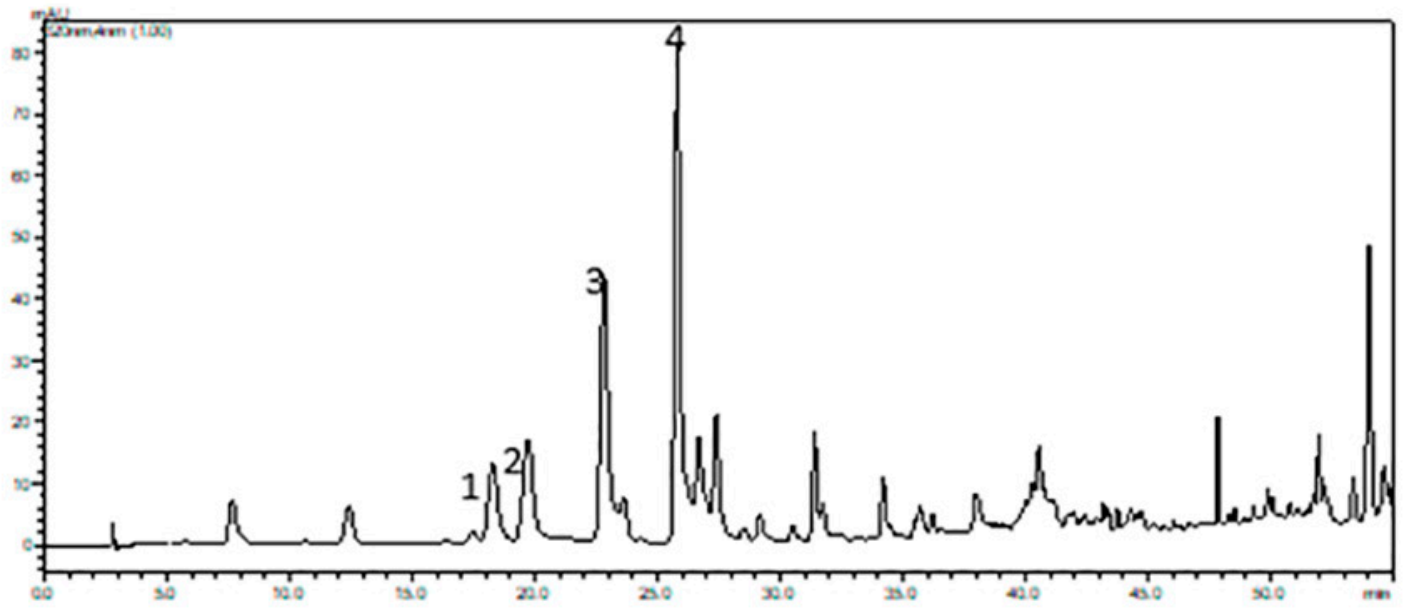

Figure 2. HPLC-DAD of the ethanolic extract from leaves of $C$. leptophloeos. *isoorientin (1), orientin (2), vitexin (3) and isovitexin (4) 
<smiles>[R]c1cc(C2Oc3cc(O)cc([R])c3CC2O)cc(O)c1O</smiles>

\section{$\mathrm{R} 1=\mathrm{R} 2=\mathrm{H} \quad$ Profisetinidina $\mathrm{R} 1=\mathrm{H}, \mathrm{R} 2=\mathrm{OH}$ Prorobinetinibrina $\mathrm{R} 1=\mathrm{R} 2=\mathrm{OH} \quad$ Prodelfinidina}

[Profisetinidin; Prorobinetinibrin; Prodelphinidin]<smiles>Oc1ccc2c(c1)OC(c1cc(O)c(O)c(O)c1)C(O)C2c1c(O)ccc2c1OC(c1cc(O)c(O)c(O)c1)C(O)C2c1c(O)ccc2c1OC(c1cc(O)c(O)c(O)c1)C(O)C2</smiles>

A Series<smiles>Oc1ccc2c(c1)OC(c1ccc(O)c(O)c1)(c1ccc(O)c(O)c1)C(O)C2c1c(O)ccc2c1OC(c1cc(O)c(O)c(O)c1)C(O)C2c1c(O)ccc2c1OC(c1cc(O)c(O)c(O)c1)C(O)C2</smiles>

B Series<smiles>Oc1ccc2c(c1)OC(c1cc(O)c(O)c(O)c1)C(O)C2c1c(O)ccc2c1OC(c1cc(O)c(O)c(O)c1)C(O)C2c1c(O)cc(O)c2c1OC(c1cc(O)c(O)c(O)c1)C(O)C2</smiles>

C Series

Figure 3. Representation of the condensed tannins structures identified in C. leptophloeos

The difference in the MBC between the two extracts was statistically significant $(\mathrm{p}<0.001)$, with lower values being found for the bark extract (Table 4). Both extracts demonstrated antimicrobial action against all isolates of Staphylococcus spp. The best activity of the leaf extract occurred at a concentration of $3125 \mu \mathrm{g} / \mathrm{mL}(36 / 60)$, and the best activity of the bark extract was achieved at a concentration of $781.2 \mu \mathrm{g} / \mathrm{mL}(24 / 60)$.

Table 4. Minimum bactericidal concentration of extracts from Commiphora leptophloeos against Staphylococcus isolates from cases of mastitis in ruminants

\begin{tabular}{ccc}
\hline & Leaf extract & Bark extract \\
\hline $\mathrm{N}$ & 60 & 60 \\
Median & $3125.00^{\mathrm{a}}$ & $781.20^{\mathrm{b}}$ \\
Mean & 3214.64 & 1261.49 \\
Standard deviation & 1441.25 & 941.82 \\
Minimum concentration & 781.20 & 390.60 \\
Maximum concentration & 6250.00 & 6250.00 \\
\hline
\end{tabular}

Different letters on same line indicate statistically significant difference $(p<0.001)$.

No statistically significant difference was found in the mean MBC for CPS and CNS isolates (1207 and $1539 \mu \mathrm{g} / \mathrm{mL}$, respectively) using the bark extract. However, a significant difference was found 
for the leaf extract ( $<<0.05$ ), with means of 2823 and $3814 \mu \mathrm{g} / \mathrm{mL}$ for CPS and CNS, respectively. A statistically significant difference was found for the bark extract with regard to isolates with and without the blaZ gene $(\mathrm{p}<0.05)$, as mean MBC values were 1146 and $1674 \mu \mathrm{g} / \mathrm{mL}$, respectively.

The leaf extract was capable of diminishing the formation of biofilm among 43 isolates, 20 of which were classified as strong biofilm producers and 20 classified as moderate producers. The bark extract was capable of interfering with the formation of biofilm in 47 isolates, 22 of which classified as strong producers and 25 classified as moderate producers (Table 1). Neither extract exerted an effect on the established biofilm.

\section{Discussion}

Ten out of the 46 positive isolates for the presence of the blaZ gene were sensitive to all antimicrobial agents tested. This finding may be explained by the absence of the complete blaZ-blaR1-blaI complex of regulating genes ${ }^{(32)}$. $\beta$-lactamase coded by the blaZ gene is regulated in the presence of an antibiotic by the adjacent genes blaI, a repressor of the blaZ transcription, and the blaR 1 antirepressor. Another important point on the resistance of Staphylococcus spp. to other antimicrobials may be related to their indiscriminate use, with the frequency and long-term employment of these drugs in the treatment of intramammary infections promoting the selection of resistant strains due to the production of $\beta$-lactamase coded by the blaZ gene ${ }^{(33,34)}$.

In the present study, the leaf and bark extracts were respectively capable of reducing biofilm formation in 43 and 47 isolates classified as from moderate to strong biofilm producers. Since the crude ethanolic extract from the leaves exhibited four main flavonoids, one might speculate that this activity could be attributed to these compounds, as Awolola et al. ${ }^{(35)}$ demonstrated the anti-biofilm-forming activity of isovitexin (a primary flavonoid found in the bark of $C$. leptophloeos in the present study) for $S$. aureus ATCC 29213. Trentin et al. ${ }^{(36)}$ report the interference of an aqueous extract from the bark of C. leptophloeos in the formation of biofilm among isolates of Staphylococcus epidermidis. In another study, Trentin et al. ${ }^{(31)}$ also verified the anti-biofilm-forming activity of an aqueous extract from the bark of C. leptophloeos applied to isolates of Pseudomonas aeruginosa, and the authors also reported the presence of condensed tannins in the extract, which is in agreement with the present findings. Moreover, the presence of gallotannins in the bark of $C$. leptophloeos is reported for the first time in the present investigation. Plants have been investigated with increasing frequency in terms of their ability to inhibit the formation of biofilm due to the demonstration of potential effectiveness with regard to antimicrobial activity against various species of microorganisms ${ }^{(37)}$.

The crude ethanolic extracts from the bark and leaves of $C$. leptophloeos demonstrated activity against all tested Staphylococcus isolates, with a significant difference in terms of the MBC, which was lower for the bark extract $(781.2 \mu \mathrm{g} / \mathrm{mL})$. This finding is due to the fact that the bark of C. leptophloeos contains condensed tannins (proanthocyanidins) that are hydrolysable. Greater antimicrobial activity was found against blaZ-positive isolates when the bark extract was employed. Thus, the results demonstrate that extracts from $C$. leptophloeos are potential antimicrobial agents. However, further studies are needed to confirm the effectiveness of these extracts against blaZ-positive isolates. In the study conducted by Trentin et al. ${ }^{(36)}$, the aqueous extract from the bark of $C$. leptophloeos exhibited antimicrobial activity against $S$. epidermidis at a concentration of $1.0 \mathrm{mg} / \mathrm{mL}$. The differences in the MBC may be attributed to the chemical composition of the antimicrobial substances in different vegetal extracts even when from the same species. An analysis of phenol compounds performed by Araujo et al. ${ }^{(38)}$ revealed a high content of flavonoids and tannins in the bark of C. leptophloeos. 
Phenols in plants are related to protection and offer a high degree of resistance to microorganisms and pests $^{(39)}$.

Other plants native to the Caatinga biome have also been tested and all have demonstrated positive antimicrobial results. Sá et al. ${ }^{(40)}$ evaluated the antimicrobial activity of six species (Amburana cearensis, Neoglaziovia variegata, Encholirium spectabile, Bromelia laciniosa, Hymenaea martiana and Selaginella convolute) against Gram-positive and Gram-negative bacteria, among which $A$. cearensis and $N$. variegate had the lowest MBC values.

In the present study, coagulase-positive staphylococci and blaZ-positive isolates were more sensitive to the C. leptophloeos bark extract. This finding is important when one considers the role of the genus Staphylococcus in the etiology of subclinical mastitis in ruminants ${ }^{(41,42)}$. The emergence of strains that are resistant to conventional antimicrobial therapy underscores the importance of seeking alternative agents, such as natural products ${ }^{(43)}$, as found in the present study.

One of the major causes of the persistence of Staphylococcus spp. in intramammary infections is the ability to form a biofilm, which makes these bacteria resistant to the antimicrobial agents used for the treatment of mastitis ${ }^{(44,45)}$. Biofilm has been found to be more resistant to antimicrobials than planktonic cells ${ }^{(46)}$. Therefore, there is an urgent need for novel anti-biofilm agents ${ }^{(47)}$. However, the strong adhesion of bacteria to surfaces hinders the removal of the established biofilm, which may explain why the extracts tested herein had no effect on established biofilm. Indeed, biofilm establishment makes it difficult to clinically treat affected animals, as the bacteria are protected from both the immune response of the host and antimicrobial agents ${ }^{(48,49)}$. According to Gonçalez-Ortiz et al. ${ }^{(50)}$, the inhibition of biofilm formation depends on phenomena linked to the enzymatic inhibition of proteases and mechanisms of quorum sensing. The stability of the biofilm is due to the deposition of proteins and carbohydrates, which hinders the action of sanitizing and antimicrobial compounds ${ }^{(51)}$.

\section{Conclusions}

Based on the present findings, ethanolic extracts from the bark and leaves of $C$. leptophloeos exhibit antimicrobial action against strains of Staphylococcus spp., as well as the ability to inhibit the formation of biofilm. Therefore, it is necessary to conduct further toxicity studies on the antimicrobial action of this species, both in vitro and in vivo, in order to advance in the phytochemical investigation of the extract fractions using different solvents, in addition to more advanced techniques, like biomarkers, highlighting the extraction of amino acids and proteins, better characterizing the potential of this plant against mastitis-causing agents in ruminants with the aim of developing products that can be used for the treatment of affected animals.

\section{Acknowledgements}

The authors are grateful to the following Brazilian fostering agencies: Coordination for the Evaluation and Improvement of Higher Education Personnel (CAPES) for awarding a Master's grant, the National Scientific and Technological Development Council (CNPq), the State of Pernambuco Assistance to Science and Technology Institute (FACEPE) and the Center for Strategic Technologies of the Northeast (CETENE). 


\section{Declaration of interest}

This manuscript has never been published. The authors are in agreement with the statements and requirements for publication. None of the authors have any conflict of interest to declare.

\section{References}

1 Kościuczuk EM, Lisowski P, Jarczak J, Krzyżewski J, Zwierzchowski L, Bagnicka E. Expression patterns of $\beta$-defensin and cathelicidin genes in parenchyma of bovine mammary gland infected with coagulase-positive or coagulase-negative Staphylococci. BMC Veterinary Research.2014;10:246.

2 Nagahata H, Kawai H, Higuchi H, Kawai K, Yayou K, Chang CJ. Altered Leukocyte Responsiveness in Dairy Cows with Naturally Occurring Chronic Staphylococcus aureus Mastitis. Journal of Veterinary Medical Science. 2011;73:885-94.

3 Ruiz AK, Peña J, González D, Ponce P. Prevalence, somatic cell count and etiology of bovine mastitis in Cuban herds from Mayabeque province using hand and machine milking. Revista Salud. Animal. 2014;36:713.

4 Dhakal IP, Dhakal P, Koshihar T; Nagahata H. Epidemiological and bacteriological survey of buffalo mastitis in Nepal. Journal Veterinary Medical Science. 2007; 69:1241-1245.

5 Gernand E, Rehbein P, Von Borstel UU, König S. Incidences of and genetic parameters for mastitis, claw disorders, and common health traits recorded in dairy cattle contract herds. Journal of Dairy Science. 2012; 95:2144-56.

6 Falentin H, Rault L, Nicolas A, Bouchard DS, Lassalas J, Lambe P, et al. Bovine Teat Análise Microbiome revelaram redução da Diversidade Alpha e mudanças significativas nos perfis taxonômicos em Quarters com uma história de mastite. Frontiers in Microbiology. 2016; 7:480.

7 Reyes-Jara A, Cordero N, Aguirre J, Troncoso M, Figueroa G. Antibacterial Effect of Copper on Microorganisms Isolated from Bovine Mastitis. Frontiers Microbiolgy. 2016;7:626.

8 Gomes F, Henriques M. Controle da mastite bovina: Abordagens terapêuticas antigas e recentes. Current Microbiology. 2016; 72:377-382.

9 Nickerson SC. Control of heifer mastitis: antimicrobial treatment-an overview. Veterinary Microbiology. 2009; 134:128-135.

10 Godden SM, Jansen JT, Leslie KE, Smart NL, Kelton DF. The effect of sampling time and sample handling on the detection of Staphylococcus aureus in milk from quarters with subclinical mastitis. Canadian Veterinary Journal. 2002; 43:38-42.

11 Tenhagen BA, Köster G, Wallmann J, Heuwiese RW. Prevalence of mastitis pathogens and their resistance against antimicrobial agents in dairy cows in Brandenburg, Germany. Journal Dairy Science. 2006;89:25422551.

12 Goni P,Vergara Y, Ruiz J, Albizu I, Vila J, Gomez-Lus R. Antibiotic resistance and epidemiological typing of Staphylococcus aureus strains from ovine and rabbit mastitis. International Journal Antimicrobial Agents. 2004; 23:268-272.

13 Harbottle H, Thakura S, Zhao S, White DG. Genetics of antimicrobial resistance. Animal Biotechnology. 2006; 17:111-124. 
14 Sheldon AT, Antibiotic resistance: a survival strategy. Clinical Laboratory Science. 2005;18: 170-180.

15Tenover F.C. \& McGowan JR.J.E. 2008. Antimicrobial resistance. International Encyclopedia of Public Health. 2008; p.211-219.

16 Olsen JE, Christensen H, Aarestrup FM. Diversity and evolution of blaZ from Staphylococcus aureus and coagulase negative staphylococci. Journal Antimicrobial Chemotherapy. 2006;57:450-460.

17 Wright GD. Bacterial resistance to antibiotics: enzymatic degradation and modification. Advanced Drug Delivery Reviews. 2005;57:1451-1470.

18 Xue T, Chen M, Shang F. Short communication: effects of lactose and milk on the expression. of biofilmassociated genes in Staphylococcus aureus strains isolated from a dairy cow with mastites. Journal Dairy Science. 2014;97:6129-6134.

19 Mendes LPM, Maciel KM, Vieira ABR, Mendonça LCV, Silva RMF, Rolim Neto PJ, et al. Atividade Antimicrobiana de Extratos Etanólicos de Peperomia pellucida e Portulaca pilosa. Revista Ciências Farmacêuticas Básica. 2011;32:121-125.

20 Mordmuang A, Shankar S, Chethanond U, Voravuthikunchai SP. Effects of Rhodomyrtus tomentosa Leaf Extract on Staphylococcal Adhesion and Invasion in Bovine Udder Epidermal Tissue Model. Nutrients. 2015;7:8503-8517.

21 Xu W, Guan R, Lu Y, Su X, Xu Y, Du A, Hu S. Therapeutic effect of polysaccharide fraction of Atractylodis macrocephalae Koidz. in bovine subclinical mastitis. BMC Veterinary Research. 2015;1:165.

22 Maia GN. Caatinga: árvores e arbustos e suas utilidades. São Paulo: Leitura \& Arte, 2004; 413p.

23 Sampaio EVSB Pareyn FGC, Figueirôa JM, Santos Junior AG. Espécies da flora nordestina de importância econômica potencial. Recife. Associação Plantas do Nordeste, 2005; 331p.

24Agra MF, Baracho GS, Silva NK, Basílio IJLD, Coelho VPM. Medicinais e venenosas diversidades da flora de "Cariri Paraibano", Brasil. Journal of Ethnopharmacology.2007; 111: 383-395.

25Abdel-Daim MM, Ghazy EW, Fayez M. S. Synergistic protective role of mirazid (Commiphora molmol) and ascorbic acid against tilmicosin-induced cardiotoxicity in mice. Canadian Journal of Physiology and Pharmacology. 2015; 93: 45-51.

26Souza Pereira JJ, Pereira APC, Jandus, JJB, da Paz JA, Crovella S, Correia MTS, Silva JA. Commiphora leptophloeos Phytochemical and Antimicrobial Characterization. Frontiers in Microiology. 2017; 8: 1-10.

27 Clinical and Laboratory Standards Institute (CLSI). Methods for Dilution Antimicrobial Susceptibility Tests for Bacteria That Grow Aerobically; Approved Standard-Ninth Edition. CLSI document M07-A9. Wayne, PA: Clinical and Laboratory Standards Institute.2012; 88p.

28 Clinical and Laboratory Standards Institute (CLSI). Methods for dilution antimicrobial susceptibility tests for bacteria that grow aerobically; Approved standards. CLSI Document M7-A7. Wayne, PA Pennsylvania. 2006; 88p.

29Nostro A, Roccaro AS, Bisignano G, Marino A, Cannatelli MA, Pizzimenti FC, Cioni, PL, Procopio, F, Blanco, AR. Effects of oregano, carvacrol and thymol on Staphylococcus aureus and Staphylococcus epidermidis biofilms. Journal of Medical Microbiology. 2007; 56:519-523.

30 Souza MP, Machado MIL, Braz-Filho R. Six flavonoids from Bursera leptophloeos. Phytochemistry. 1989,28: 2467-2470. 
31 Trentin DS, Silva DB, Amaral MW, Zimmer KR, Silva MV, Lopes NP, et al. Taninos possuindo bacteriostatic Efeito Impair Pseudomonas aeruginosa adesão e formação de biofilme. Plos One. 2013;8:66-257.

32Mendonça ECL, Marques VF, Melo DA, Alencar TA, Coelho IS, Coelho SMO, Souza MMS. Caracterização fenogenotípica da resistência antimicrobiana em Staphylococcus spp. isolados de mastite bovina. Pesquisa Veterinária Brasileira.2012;32:859-864.

33Pitkälä A, Haveri M, Pyörälä S, Myllys V, Honkanen-Buzalski, T. Bovine mastitis in Finland 2001Prevalence, distribution of bacteria, and antimicrobial resistance. Journal Dairy Science.2004;87:2433-2441

34Kumar R., Yadav B.R. \& Singh R.S. Genetic determinants of antibiotic resistance in Staphylococcus aureus isolates from milk of mastitic crossbred cattle. Current Microbioloy. 2009;60:379-386.

35 Awolola GV, Koorbanally NA, Chenia H, Shode FO, Baijnath H. Antibacterial and Anti-Biofilm Activity of Flavonoids and Triterpenes Isolated from the Extracts of Ficus sansibarica Warb. Subsp. Sansibarica (Moraceae) Extracts. African Journal of Traditional, Complementary, and Alternative Medicines. 2014;11:124131

36 Trentin DS, Giordani RB, Zimmer KR, Silva AG, Silva MV, Correia MT, et al. Potential of medicinal plants from the Brazilian semi-arid region (Caatinga) against Staphylococcus epidermidis planktonic and biofilm lifestyles. Journal of Ethnopharmacology. 2011;137:327-335.

37 Pereira JV, Pereira MSV, Sampaio FC, Sampaio MCC, Alves PM, Araújo CRF, Higino JS. Efeito antibacteriano e antiaderente in vitro do extrato da Punica granatum Linn. sobre microrganismos do biofilme dental. Revista Brasileira Farmacognosa. 2006;16: 88-93.

38 Araujo TAS, Alencar NL, Amorim ELC, Albuquerque UP. A new approach to study medicinal plants with tannins and flavonoids contents from the local knowledge. Journal of Ethnopharmacology.2008;120:72-80.

39 Everette JD, Bryant QM, Green AM, Abbey YA, Wangila G W, Walker RB. Thorough study of reactivity of various compound classes toward the Folin-Ciocalteou reagent. Journal of Agricultural Food Chemistry. 2010; 58:139-144.

40 Sá MCA, Peixoto RM, Krewer CC, Almeida JRG, Vargas AC, Costa MM. Antimicrobial activity of caatinga biome ethanolic plant extracts against gram negative and positive bacteria. Revista Brasileira de Ciência Veterinária. 2011;18:62-66.

41 Coelho SMO, Reinoso E, Pereira IA, Soares LC, Demo M, Bogni C, Souza MMS. Virulence factors and antimicrobial resistance of Staphylococcus aureus isolated from bovine mastitis in Rio de Janeiro. Pesquisa Veterinária Brasileira. 2009; 29:369-374.

42 Taponen S, Pyörälä S. Coagulase-negative staphylococci as cause of bovine mastitis not so different from Staphylococcus aureus? Veterinary Microbiology. 2009;134:29-36.

43 Godreuil S, Leban N, Padilla A, Hamel R, Luplertlop N, Chauffour A, et al. Structure and Antimicrobial Activity against Multidrug Resistant Bacterial Strains. PLoS ONE. 2014; 9:1371.

44 Nasr RA, AbuShady HM, Hussein HS. Biofilm formation and presence of icaAD gene in clinical isolates of staphylococci. Egyptian Journal of Medical Human Genetics. 2012;13:269-274.

45 Terki IK, Hassaine H, Oufrid S, Bellifa S, Mhamed I, Lachachi M,Timinouni M, Detection of icaA and icaD genes and biofilmformation in Staphylococcus spp. isolated from urinary catheters at the University Hospital of Tlemcen (Algeria). African Journal Microbiology Research. 2013;7:5350-5357.

46 Jadhav S, Shah R, Bhave M, Palombo EA. Inhibitory activity of yarrow essential oil on Listeria planktonic cells and biofilms. Journal Food Control. 2013;29:125-130. 
47 Schilaci D, Arizza V, Dayton T, Camarda L, Di Stefano V. In vitro anti-biofilm activity of Boswellia spp. oleogum resin essential oils. Letters in Applied Microbiolog. 2008;47:433-8.

48 Drenkard E. Antimicrobial resistance of Pseudomonas aeruginosa biofilms. Microbes and Infection. 2003; $5: 1213-1219$.

49 Hoyle BD, Costerton JW. Bacterial resistance to antibiotics: the role of biofilms. Progress in Drug Research. 1991;37:91-105.

50 Gonzalez-Ortiz G, Perez JF, Hermes RG, Molist F, Jimenez-Diaz R, Martin-Orue SM. O rastreio da capacidade de ingredientes de alimentos naturais para interferir com a aderência de enterotoxigenic Escherichia coli (ETEC) K88 ao muco intestinal suína. British Journal of Nutrition. 2014; 111:633-642.

51 Wang H, Ding S, Wang G, Xu X, Zhou G. In situ characterization and analysis of Salmonella biofilm formation under meat processing environments using a combined microscopic and spectroscopic approach. International Journal Food Microbiology. 2013;167:293-302. 